Persp. Teol. 35 (2003) 187-213

\title{
OS MONGES E A TORRE DE BABEL
}

Olga Sodré

\section{Passagem para o pós-modernismo e cultura do diálogo}

O presente artigo procura situar o diálogo inter-religioso monástico, no contexto das transformações da subjetividade, características do período histórico, que está sendo chamado de "pós-modernidade". Pretendo pôr em evidência a relação entre a crise das formas de pensamento e de explicação do mundo da "modernidade" com a abertura para a pluralidade do ser e o surgimento do diálogo inter-religioso, mostrando como essa ruptura com o chamado "pensamento moderno" ocorreu concretamente, no meio intelectual francês, ao qual eu estava integrada, na época. Percebo, agora, que tal ruptura correspondeu, de fato, a uma passagem para a "pós-modernidade", com sua dimensão plural, com seu novo interesse pela religião, com sua necessidade de diálogo e de desenvolvimento da hermenêutica. A apresentação desse processo histórico me permitirá, então, introduzir a fenomenologia hermenêutica de Paul Ricoeur e sua importância para a filosofia e para as ciências humanas e sociais, na atualidade, indicando a contribuição, que sua concepção do ser pode trazer para o diálogo inter-religioso.

Foi, no final dos anos sessenta e mais claramente na década de 70, que se aceleraram as transformações da cena intelectual francesa, que pro- 
piciaram a aparição da obra de Jean-François Lyotard, $A$ condição Pós-moderna, publicada em 1979, pela qual esse tema é lançado no meio acadêmico. A elaboração do pensamento intelectual sobre a questão antecede, contudo, o aparecimento dessa obra, como mostrarei a seguir. Na realidade, muitos de seus elementos começam a germinar na década de sessenta, despontando com mais profundidade nas ciências humanas por volta de 1968. Surgem, então, transformações sociais, que favorecem o amadurecimento do movimento, e o fazem emergir de forma inicialmente incoerente, até ir tomando sentido ao longo dos anos setenta.

As décadas de sessenta a oitenta estabelecem um marco importante para a "cultura do diálogo", coincidindo com uma virada fundamental no reconhecimento do pluralismo religioso. O Vaticano II (19621965) abre oficialmente as portas do catolicismo para o diálogo interreligioso. Em 1968, o congresso asiático de monges católicos passa a contar com a presença de monges de outras tradições orientais; em 1978, é eleito o Papa João Paulo II, que muito vem contribuindo para a promoção do diálogo inter-religioso. Nesse mesmo ano, surgem as primeiras comissões para o Diálogo Inter-religioso Monástico, dando início efetivo às atividades institucionais do diálogo inter-religioso monástico (DIM). Em 1986, o Papa João Paulo II promove uma reunião inédita entre os representantes das mais diferentes religiões, em Assis (Itália).

Meu enfoque da "cultura do diálogo", embora procurando cernir a questão ao nível religioso, leva também em conta as transformações da tecnologia e da cultura, no processo histórico de transformação social, que engendrará as características fundamentais da "pósmodernidade". É a partir da análise desse processo e em relação com essas características, que procurarei apresentar o "renascimento da religião" ou o "retorno da religião", observado no mesmo período. Baseando-me em alguns filósofos pós-modernos, mostrarei que esse "renascimento da religião" pode ser considerado como uma das características da etapa histórica atual, chamada de "pós-modernidade".

Na França, no período anterior a 1968, o movimento aéreo era ainda fraco, as pessoas se vestiam predominantemente de cinza e marrom, os estrangeiros eram pouco numerosos e as ruas tranqüilas, mesmo tarde da noite. A integração européia era ainda apenas um projeto. No meio intelectual francês, o discurso era moldado por um racionalismo extremamente formal, articulado e linear. Até mesmo na École Pratique des Hautes Études (EPHE), onde havia uma vanguarda de pesquisadores das ciências humanas e sociais, predominava esse tipo de racionalismo. A equipe de psicologia social, por exemplo, na qual eu trabalhava, na época, fazia pesquisa de campo, mas dava mais importância ao aspecto quantitativo e ao uso do método experimental. 
A EPHE tinha um projeto de formar pesquisadores sociais de alto nível e, para isso, criou um ensino de pós-graduação especializado em pesquisa, o Ensino Preparatório à Pesquisa Aprofundada em Ciências Sociais (EPRASS), pois, antes de 1968, a pesquisa não tinha ainda sido introduzida no ensino universitário das ciências humanas e sociais. $\mathrm{O}$ EPRASS tornou-se uma expressão desse racionalismo aplicado à pesquisa social, dando grande ênfase à lógica, à matemática moderna e aos métodos estatísticos e experimentais. Ao mesmo tempo em que se desenvolvia esse meio científico, forjava-se, igualmente, no meio intelectual e universitário, um movimento estudantil e um movimento feminino, onde estavam sendo elaboradas novas formas de discurso. Cursando o EPRASS e participando desses movimentos, eu me encontrava na confluência desses discursos e contradições.

Foi nesse contexto, que surgiu a revolução estudantil de 1968, que pretendia levar a imaginação ao poder, e acabou sacudindo os alicerces da universidade francesa, onde predominava o ensino especulativo, distante da realidade social e da pesquisa de campo, aprofundada pela EPHE Uma das conseqüências da efervescência cultural, que brotou com o movimento de 68 , foi a eclosão de novas teorias sociais, assim como uma radical mudança no ensino universitário e no pensamento intelectual. Estávamos no início da década de setenta, e a vida parisiense havia mudado bastante. $\mathrm{O}$ movimento psicodélico havia generalizado o uso diversificado das cores, principalmente nos grandes centros urbanos. As relações sociais eram menos formais e a cidade havia se expandido para a periferia, onde crescia o número de imigrantes, fazendo surgir um grande interesse pela sociologia urbana, pelo meio ambiente e pelo trabalho social com os diferentes grupos culturais, trazidos pela imigração.

Começou, então, a ocorrer uma grande reviravolta na maneira de ver e pensar o mundo, que caracterizou a passagem do pensamento moderno para o "pós-modernismo". Surgem, no movimento feminista, tentativas de romper com o "discurso racionalista masculino", voltando-se mais para a experiência vivida, para o imaginário e para o corpo. Paris estava mudando e já havia um intercâmbio internacional mais acentuado, em particular o início de uma forte influência cultural americana, que podia ser observada até nas modificações da aparência e do modo de funcionamento dos cafés e restaurantes. É nesse contexto, que começam a ser introduzidas, no meio intelectual, as experiências americanas de trabalho corporal e de pesquisa da mente, que encontram o terreno preparado pelo discurso do feminismo. Outra coisa que estava mudando, era o cenário da psicologia e da psicanálise, em face ao desenvolvimento das técnicas corporais e do interesse pelas experiências espirituais, em particular as de tipo oriental. Um fator fundamental nesse processo de mudança foi justamente o "retor- 
no" à espiritualidade e a maneira como esse "retorno" aconteceu, no intercâmbio com culturas muito antigas, como a cultura indiana, que soube preservar sua riqueza imaginária e sua relação com o sagrado.

Fala-se de "retorno" nesse caso, para sublinhar a volta do interesse social pela espiritualidade e pela religião. Esse interesse ressurge, na Europa da década de setenta, como um movimento heterogêneo, trazendo em seu bojo diferentes níveis e tipos de contribuição. Uma das contribuições mais positivas desse "retorno da religião" é o aumento do número de publicações sobre a psicologia da religião, a partir dos anos sessenta/setenta, como mostra Mario Aletti ${ }^{1}$, em sua revisão da história da psicologia da religião, na Itália. Existia já uma produção intelectual anterior sobre o assunto, mas essa produção se expande e se aprofunda, nesse período. Multiplicam-se, ao mesmo tempo, as visões críticas sobre a psicanálise e o marxismo, antes hegemônicos no meio intelectual. O próprio Aletti, psicanalista e professor de psicologia da religião na Faculdade Teológica de Milão, faz uma releitura crítica da obra de Freud sobre a religião ${ }^{2}$.

Não se estava recusando em bloco o marxismo ou a psicanálise, que contribuíram de modo fundamental para as ciências humanas e sociais. O que se passou a recusar foi a utilização da psicanálise e do marxismo como visões globais e totalizadoras, que excluíam, ao mesmo tempo, uma série de experiências humanas fundamentais, como, por exemplo, a experiência religiosa. Recusava-se, igualmente, um modo racionalista de abordar os problemas humanos, pretendendo explicar o mundo de forma linear e determinista, em termos de causa e efeito. Assim sendo, não se tratava de uma revolta contra a razão e de um "retorno" ao irracionalismo, mas de uma ruptura com um certo tipo de uso da razão e da ciência próprias do modernismo.

\section{Características da pós-modernidade}

A passagem para a "pós-modernidade", que acabo de descrever, foi um processo de profundas mudanças sociais, que continuaram a ocorrer, após esse início por mim descrito, na direção da sua consolidação, ao longo das últimas décadas do segundo milênio. Nesse processo tiveram grande influência as transformações tecnológicas, já em curso nas décadas anteriores, mas que se acentuaram a partir das décadas de oitenta e noventa. Observa-se, nesse período, a aceleração da revo-

${ }^{1}$ M. ALETTI, Psicologia, psicanalisi e religione, Bologna: Centro Editoriale Devoniano, 1992, pp. 9-26.

${ }^{2}$ Ibidem, pp. 83-95. 
lução da informação, da globalização, da formação da sociedade em rede (em particular, após a introdução da Internet), assim como a transformação dos meios de comunicação (como é o caso da telefonia, levando à multiplicação do uso dos celulares).

Essas transformações tecnológicas imprimem uma dimensão e uma fisionomia cada vez mais marcantes à cultura pós-moderna, de modo que se passa a falar mesmo de cultura digital. Surgem novas formas de relacionamento humano, uma nova linguagem e novas configurações da subjetividade, nesse início do Terceiro Milênio. Esse processo é atual e está em plena evolução. Estamos, de fato, assistindo à formação da "pós-modernidade" e da cultura digital, marcadas pelo pluralismo e por um diálogo interpessoal, que se estende a todo o globo. História, cultura e psique se entrelaçam na constituição dessa nova formação psicossocial, como mostrou muito bem Monique Augras: "Vale dizer: cultura e sociedade não são quadros externos dentro dos quais a pessoa vai se desenvolver. São aspectos constitutivos da própria personalidade. $\mathrm{O}$ homem concreto é produto, além de produtor, de todo o aparato sócio-cultural, tanto nos aspectos simbólicos como estritamente técnicos" ${ }^{\prime \prime}$.

Considero importante para a reflexão sobre a "pós-modernidade" partir da contribuição de Lyotar (1979), pois ele descreve o processo de ruptura com a modernidade, mostrando o fim dos "meta discursos" e dos grandes sistemas teóricos totalizadores, por ele chamados de "Grandes Relatos". Esse processo já era nítido, na década de setenta, e havia começado mesmo antes, na filosofia, com o fim da metafísica. Lyotar assinala, que o desenvolvimento científico, em diferentes áreas, torna impossível descrever e analisar o mundo através dos discursos universais anteriores. Ele apresenta sua concepção desse desenvolvimento como a formação de um conjunto heterogêneo de discursos, impossíveis de serem unificados numa meta linguagem universal, como a que a ciência possuía na modernidade. Esses discursos especializados e próprios de cada área do conhecimento passam, então, a ser submetidos às regras próprias de legitimação de cada comunidade científica.

As reflexões epistemológicas de Lyotar e de Gianni Vattimo põem em evidência o surgimento de uma visão do mundo complexa, instável, fragmentada e imprevisível, que dá origem a uma multiplicidade de narrativas sobre um mundo múltiplo ou plural. Esses autores não deixam de levar em conta as transformações capitalistas e o desenvolvimento das tecnologias digitais, conduzindo à valorização e descentralização da informação, que propiciaram a multiplicação do

${ }^{3}$ M. AUGRAS, Alteridade e dominação no Brasil - psicologia e cultura, Rio de Janeiro: NAU, 1995, p. 19. 
capital e dos bens de consumo, assim como a circulação veloz da informação. Eles desvendam as transformações ocorridas no nível das formas de pensamento e dos discursos, permitindo de melhor compreender como a utilização da informática na produção e transmissão do conhecimento acaba por transformar o próprio conhecimento, rompendo a trama das visões enciclopédicas e universalistas.

O conceito de "pós-modernismo" é bastante discutível e impreciso, mas ele permite distinguir o período atual, que estamos vivendo, do período anterior, que ficou conhecido como "modernidade". RomãoDias $^{4}$ coloca em evidência as reservas sobre esse conceito, mostrando como Kaplan considera tal conceito de "pós-modernismo" como contraditório e a idéia de que ele introduziria uma ruptura como problemática, observando que "(...) a diversidade e divergência de conceitos vêm dando uma forma confusa à pós-modernidade". Ambas sublinham, contudo, que a heterogeneidade é uma marca da "pósmodernidade", que seria "(...) justamente, uma época marcada pelo fim dos universalismos" ${ }^{\prime \prime}$.

Romão-Dias postula, também, que o termo assinala um movimento para além das teorias totalizantes anteriores, cujo desaparecimento pode ser percebido como emancipador ou como negativo. Escrevendo num período posterior a Lyotar, Vattimo vai se dar conta dos sentimentos negativos e nostálgicos em face às transformações do mundo e à tecnologia digital, na "pós-modernidade". Ele abre, porém, a perspectiva para um outro tipo de relação positiva com essas transformações do processo de conhecimento, por ele caracterizado pela pluralidade. Ao contrário de Lyotar e Vattimo, os autores de influência marxista (tais como Jameson, Harvey e Bauman) acentuam, contudo, o aspecto social negativo das transformações tecnológicas, considerando que o acesso à informação é ainda restrito, estratificador, promovendo a exclusão, a rigidez e a intolerância nas relações sociais.

Muito valiosa e inovadora é, sem dúvida, a contribuição de Manuel Castels, com quem estudei, quando ele ainda trabalhava em sociologia urbana, em Paris, na EPHE, em meado dos anos setenta. Posteriormente, trabalhando nos Estados Unidos, ele escreveu sobre a sociedade em rede ${ }^{6}$, sublinhando o papel das redes interativas de computadores na criação de novas formas e canais de comunicação, que moldam a vida e vem por ela sendo moldadas. A utilização dessa

\footnotetext{
${ }^{4}$ D. ROMÃO-DIAS, Nossa plural realidade: um estudo sobre a subjetividade na era da Internet $=$ dissertação de mestrado, Rio de Janeiro: Departamento de Psicologia da PUC-Rio, 2001.

${ }^{5}$ Ibidem, p.11.

${ }^{6}$ M. CASTELS, A sociedade em rede, São Paulo: Paz e Terra, 1999.
} 
rede, no diálogo inter-religioso, vem diminuindo as distâncias espaciais e favorecendo a formação de novos espaços virtuais de comunicação entre tradições religiosas, enraizadas nos pontos mais distantes do planeta. Nesse sentido, a penetração das novas tecnologias digitais influenciam todas as esferas da existência. Essa influência ocorre não somente na área produtiva, no comércio, lazer e entretenimento, mas também na área religiosa, modificando o campo dos relacionamentos pessoais mesmo entre monges, que vivem uma vida mais reclusa, retirados das atividades mundanas. Além disso, a estrutura descentralizada e complexa das redes, vem permitindo o aparecimento de novas formas de intercâmbio e organização, no diálogo inter-religioso monástico. Ela possibilita, por exemplo, a troca de informações internacionais e a divulgação de testemunhos dessa nova experiência religiosa. Permite, igualmente, a visualização, a reflexão, as publicações e comunicações sobre as mudanças no DIM.

A nova tecnologia digital contribui, também, para a abertura da subjetividade, que considero uma característica central do DIM, permitindo o intercâmbio e o acesso múltiplo e variado à experiências religiosas diversas. Nesse sentido, a experiência do DIM não só se beneficia das novas tecnologias, mas manifesta o surgimento, no contexto religioso, das novas categorias de análise do mundo. Como assinalou Castels, as transformações tecnológicas têm influenciado nossas categorias de pensamento no sentido da "(...) abertura como uma rede de acessos múltiplos"7. Através do DIM, criou-se uma nova rede de relações entre os monges de diferentes religiões, estruturando novas formas de troca, de vivência e de maneiras de ver e pensar a si mesmo e os outros, mais flexíveis e abertas à diversidade. A teoria de Castels fornece uma interessante perspectiva de compreensão da nova subjetividade aberta, diferenciada e múltipla, que está em elaboração, no DIM.

Não pretendo estudar o impacto da revolução tecnológica da informação e da cultura digital sobre o diálogo inter-religioso ou sobre a vida, a organização e a subjetividade monásticas. É, contudo, importante assinalar, que novos tipos de relação e de subjetividade estão em gestação no meio religioso e não podem ser separadas desse processo. $\mathrm{O}$ DIM está inserido nas transformações da "pós-modernidade" e da cultura digital. Concordo nesse sentido com as conclusões de Ana Maria Nicolaci-da-Costa ${ }^{8}$, que as novas formas de organização social

\footnotetext{
7 Ibidem, p. 81.

8 A. M. NICOLACI-DA-COSTA, Estamos diante de uma nova revolução?: Investigando os impactos psicológicos do uso de celulares multifuncionais = Projeto de Pesquisa, Rio de Janeiro: Departamento de Psicologia da PUC-Rio, 2001, p. 13.
} 
(virtual e em rede), o novo espaço virtual e o uso de celulares multifuncionais estão gerando alterações nos comportamentos e em nossa atual configuração psíquica, inclusive entre os monges.

Em seu livro, Na Malha da Rede ${ }^{9}$, Ana Maria Nicolaci-da-Costa já havia descrito os novos conceitos, a nova lógica, a nova linguagem e os novos modos de relação surgidos com o uso da Internet. Ana Maria Nicolacci-da-Costa se interessa, sobretudo, pelos aspectos psicológicos desse processo de mudança social e se refere, em particular, à nova forma de organização subjetiva dos "sujeitos multiplicados" de Sherry Turkle ${ }^{10}$ ou dos "sujeitos plurais" de Romão-Dias ${ }^{11}$. Esses trabalhos mostram, que a revolução das tecnologias de informação está alterando as relações entre as pessoas, fazendo surgir um novo tipo de organização subjetiva "plural", novas formas de sentir, de pensar, de se perceber e perceber o mundo, novas maneiras de ver a realidade (distinguindo o virtual tanto da fantasia como do real) e novos modos de lidar com a fragmentação e a multiplicidade do ser. Seria, portanto, interessante, apresentar, agora, como o caminho monástico aborda a questão da unidade e da multiplicidade do ser.

\section{Os monges e as transformações da subjetividade}

Pesquisando a vida monástica da tradição hindu e católica, observei a relevância para os dois caminhos de um processo de reelaboração do eu e de sua relação com o outro. $\mathrm{O}$ ingresso na vida monástica é sempre acompanhado pela renúncia das identidades e relações sociais anteriores, inclusive familiares: as vestimentas sociais são trocadas pelos trajes monásticos, o nome social é substituído pelo nome espiritual, os bens materiais são doados, os antigos laços ou situações sociais são abandonados. Busca-se um descentramento do eu, um recolhimento, uma outra forma de abertura e de presença a si mesmo, aos outros e a Deus. Em ambas as tradições, recusa-se, assim, à perspectiva de divisão e secessão das consciências para aceder-se a uma visão de unidade e igualdade entre os seres humanos, de intersubjetividade e de integração com Deus, consigo mesmo, com os outros e com o universo, canalizando todas as energias para a realização desse processo de unificação e abertura da consciência.

${ }^{9}$ A. M. NICOLACI-DA-COSTA, Na malha da Rede: os impactos íntimos da Internet, Rio de Janeiro: Editora Campus, 1998.

${ }^{10} \mathrm{~S}$. TURKLE, Life on screen: identity in the age of the Internet, New York: Touchstone, 1995.

${ }^{11}$ ROMÃO-DIAS, op. cit. 
Verifiquei, contudo, uma diferença fundamental entre as duas tradições no que diz respeito à representação de Deus. No hinduísmo, Deus é identificado com o Si mesmo (o Self). Ele é o mesmo e único Ser, em todos os seres, havendo uma identidade entre Deus e o ser em cada um de nós. Embora a divindade receba diversos nomes, procurase chegar a uma visão do mesmo e único Ser em tudo e em todos, predominando o processo de reconhecimento de uma mesma identidade divina universal. A santificação é assim um processo de iluminação ou de descoberta da própria divindade comum a todos os seres humanos. No cristianismo, ao contrário, Deus é considerado como o totalmente Outro e cada pessoa tem o seu próprio ser, distinto do ser divino. Predomina, portanto, uma perspectiva de alteridade e a santificação, nesse caso, estabelece-se, através de uma relação com Deus e uma participação na divindade do próprio Deus, mantendo-se a diferença radical entre o eu e o Outro.

Não tenho dúvida de que as raízes do DIM foram lançadas bem antes da época atual, em particular, pela presença de mosteiros cristãos, na Índia. Não apenas ocorreu a influência cristã sobre a devoção às formas pessoais da divindade (movimento bakti), como a consolidação dessa experiência de intercâmbio cultural levou, igualmente, à inculturação de certos aspectos da vida religiosa hindu pelo catolicismo, na forma de ashrams católicos, por exemplo. A proposta de diálogo entre monges hindus e cristãos é, porém, mais recente, manifestando-se de forma mais oficial nos Congressos Monásticos católicos, a partir de 1968, e na criação de comissões para o DIM, em 1978. Minha participação na comissão européia do DIM, desde 2000, meu contato pessoal com os monges e o acesso aos boletins da Comissão, contendo relatos de monges da tradição beneditina, permitiram $o$ aprofundamento de minha reflexão sobre o diálogo inter-religioso.

Percebi, então, que o testemunho dos monges pode contribuir para a psicologia, na medida em que ajude a lançar luzes sobre a questão mais ampla da constituição e transformação da subjetividade e sua abertura, assim como sobre a unidade/pluralidade do ser e a relação à alteridade. Os testemunhos dos monges põem em evidência que, embora percorrendo um caminho interior, eles não apenas se situam numa determinada tradição cultural, com raízes histórico-sociais, mas rompem radicalmente com a separação entre interior e exterior, chegando através do processo de abertura e transcendência da consciência a uma visão de unidade e dissolução dessas divisões e dicotomias. Esses testemunhos confirmam a relatividade da subjetividade de tipo individual, fechada nas próprias idéias, emoções e pensamentos. Eles nos fazem pensar se não seria precipitado reduzir o ser humano a sua dimensão meramente social, tornando a subjetividade um mero reflexo do social e excluindo a dinâmica própria das transformações psicológicas e das formas de interioridade espiritual. 
As comissões para o DIM reúnem monges de diferentes religiões em torno de uma forma nova de intercâmbio, centrada no diálogo da experiência, no qual se procura a convivência e a prática em comum, de modo a ultrapassar as barreiras e a falta de compreensão das diferenças religiosas. Assim sendo, os monges de uma tradição visitam e participam da vida e das práticas de mosteiros de outras tradições religiosas. $\mathrm{O}$ testemunho dessa experiência é relatado e partilhado, em seguida, com os monges, que integram as diferentes comissões do DIM, em diversos países. Trata-se de uma experiência ainda recente, mas ela me parece indicar uma tendência inovadora na relação entre as religiões ocidentais e orientais (cristianismo, hinduísmo, budismo e islamismo). Desse ponto de vista, ela é fruto não apenas do esforço pessoal de alguns pioneiros, que abriram caminho nesse sentido (como, por exemplo, os monges beneditinos que criaram novas práticas ou formas de vida monástica na Índia ou no Japão), mas também das transformações religiosas e sociais da atualidade.

Tendo retornado ao catolicismo, em 1992, após uma longa caminhada pela espiritualidade oriental e uma intensa prática da meditação, estranhei inicialmente a dimensão mais externa e "social" das práticas cristãs. Constatei que refletiam a crescente agitação do modo de vida urbano, na qual predomina a ausência de recolhimento e a falta de introspeção e contato consigo mesmo. Ao entrar em contato com as diferentes formas de contemplação cristã, descobri, contudo, que o cristianismo, também, coloca ênfase no recolhimento, para o desenvolvimento da vida interior com Deus. Cheguei, portanto, à conclusão que o "ativismo" não era próprio à vida espiritual cristã, mas fruto das condições sociais, nas quais se desenvolve o cristianismo na atualidade. Embora, no cristianismo, dê-se mais importância à ação, essa não é um fim em si, devendo brotar da relação primordial e íntima com Deus.

Tanto o caminho espiritual da ioga como a vida mística cristã exigem, ao contrário, uma interiorização da consciência, que se desliga (inicialmente, ao menos durante as práticas espirituais) da atividade externa dos sentidos e do modo de funcionamento do mundo material, para poder desenvolver a vida espiritual. Essa interiorização é uma condição para possibilitar a abertura interior da consciência, permitindo um outro tipo de escuta de si mesmo, dos outros e de Deus. A idéia da abertura interior para o alto e para Deus é desenvolvida de um modo particularmente interessante pelo teólogo K. Rahner ${ }^{12}$.

Considera ele que o materialismo, ao proclamar a morte de Deus, produziu uma visão do mundo, na qual o homem fica sendo o centro e ocupa uma posição onipotente de super-homem sem transcendência,

${ }^{12}$ K. RAHNER, Curso fundamental da fé, São Paulo: Paulus, 1989. 
perdendo a referência à um centro fora de si mesmo. Rahner parte da observação do ser humano, considerando-o como um ser que pode estar presente a si mesmo e refletir sobre si mesmo e sobre seu saber ${ }^{13}$. Aborda, então, a possibilidade de uma abertura da pessoa para o fundamento do seu ser, de uma capacidade de transcendência e de abertura para o mistério de Deus. Essa abertura interior da consciência possibilita uma perspectiva descentrada (ou sem um centro na própria pessoa), mas voltada para a alteridade, tanto divina quanto humana.

As rupturas externas próprias da vida monástica são necessárias ao desenvolvimento desse tipo de vida espiritual, exprimindo-se na forma da vida recolhida dos mosteiros. Essa ruptura, exigida tanto na tradição da ioga como na tradição cristã, implica um abandono das identificações sociais e de outros apegos e propensões naturais, que possam ser um obstáculo a um encontro mais profundo com Deus. Implica, também, uma diminuição da comunicação externa supérflua para o desenvolvimento interior da vida espiritual. Esse processo não requer, contudo, a exclusão do progresso tecnológico das comunicações, que está sendo usado, por exemplo, para manter a comunicação entre os mosteiros, inclusive no diálogo inter-religioso.

O que se busca através dessa ruptura é uma predominância e ampliação do espaço interior para abrigar uma crescente vida espiritual. Ela é necessária ao aperfeiçoamento de uma percepção espiritual, indispensável à contemplação de Deus. Esse espaço interior do sagrado não é, todavia, um espaço particular, privado e individual. É um erro imaginá-lo como uma forma de afastamento dos outros seres, já que se trata do espaço onde predomina o amor de Deus, que é doação e comunicação do próprio ser. Daí a importância da vida religiosa em comunidade e da inserção dos mosteiros na vida comunitária mais ampla, na qual se tornam focos de paz e repouso em Deus, em meio à agitação do nosso mundo. A vida dos santos é um exemplo de que um certo tipo de recolhimento espiritual, necessário para uma união mais intensa com Deus, é a base de uma abertura muito mais ampla e abrangente para todos os outros seres, implicando uma maior doação e entrega de si mesmo ao outros.

Procurarei mostrar, a seguir, qual é a relação entre essa nova forma de diálogo inter-religioso e as transformações psicológicas, sociais e tecnológicas de um mundo globalizado, e como ela se integra ao movimento da chamada "pós-modernidade" e ao surgimento de novas formas de subjetividade. Para isso, eu me servirei de um debate entre filósofos a respeito do atual "ressurgimento do religioso", sua relação com a "pós-modernidade" e com a cultura digital.

${ }^{13}$ Ibidem, p. 30. 


\section{Pós-modernidade, cultura digital e religião}

Em 1994, alguns filósofos europeus, entre eles Jacques Derrida, Gianni Vattimo e Hans-Georg Gadamer ${ }^{14}$, reuniram-se na ilha de Capri, tendo em vista o projeto de criação de um Anuário Filosófico Europeu, e escolheram como tema a religião, admitindo seu caráter central para nossa época. Na sua intervenção nesse encontro, Derrida se pergunta: "Por que esse fenômeno, prematuramente denominado 'o retorno das religiões', é tão difícil de se pensar? Por que ele surpreende? Por que se espantam, em particular aqueles que acreditavam ingenuamente, que uma alternativa opunha de um lado a Religião, do outro a Razão, o Iluminismo, a Ciência, a Crítica (a crítica marxista, a genealogia nietzscheana, a psicanálise freudiana e suas heranças) como se uma não pudesse senão acabar com a outra?"15.

Gadamer, em sua conclusão final, observa tratar-se para os participantes, em particular Derrida e Vattimo, “(...) de se liberarem de todo dogmatismo e, sobretudo, daquele que não quer ver na religião senão engano, ou a ilusão que o homem se infringe a ele próprio"16. Ele sublinha, igualmente, que as tomadas de posição de ambos têm em vista a ultrapassagem da metafísica, tal como foi colocada por Heidegger. Trata-se, portanto, de um fato filosófico novo e não de um retorno à metafísica, com suas colocações de tipo essencial, conclui Gadamer. De fato, esses filósofos partem dessa nova perspectiva da filosofia para analisar a posição da religião em seu atual contexto social. Derrida, por exemplo, descreve a relação da religião com a cultura digital e com as novas técnicas de telecomunicação, presentes em todo tipo de manifestação religiosa, quer seja uma viagem ou alocução papal, um evento relacionado com o Dalai-Lama ou uma manifestação de cura $^{17}$.

Considera ele, portanto, uma cegueira "(...) continuar opondo tão ingenuamente Razão e Religião, Crítica ou Ciência e Religião, a Modernidade técnico-científica e a Religião"18. Continuar a crer nessa oposição, ou seja, nessa incompatibilidade, seria permanecer numa certa tradição do Iluminismo, a de uma "certa vigilância crítica e antireligiosa, anti-judaico-cristã-islâmica, uma certa filiação 'VoltaireFeuerbach-Marx-Freud e mesmo Heidegger'"19. Apesar dessas constatações, é Vattimo quem me parece realmente aprofundar a

${ }^{14}$ J. DERRIDA / G. VATTIMO (orgs.), La religion, Paris: Seuil, 1996.

${ }^{15}$ Ibidem, p. 13. Todos os trechos desta obra citados neste artigo são tradução do francês pela autora.

${ }^{16}$ Ibidem, p. 228.

${ }^{17}$ Ibidem, pp. 35-36.

${ }^{18}$ Ibidem, p. 40.

${ }^{19}$ Ibidem, pp. 40-41. 
questão da relação do atual "ressurgimento do religioso" (que ele observa através da nova vitalidade das igrejas, das seitas, das doutrinas e práticas, da "moda" das religiões orientais) com as transformações da "pós-modernidade".

Propõe-se ele a pensar as modalidades concretas desse "retorno" em condições históricas determinadas. Ele assinala um aspecto fundamentalista nesse "retorno", caracterizado pela afirmação freqüentemente violenta das identidades locais e étnicas, acompanhada de uma recusa da modernização, em face ao risco da destruição de raízes culturais. Mostra, porém, mudanças do lado da filosofia e da reflexão, que estão em oposição com essa dimensão fundamentalista. Ele as relaciona ao desabamento das proibições filosóficas contra a religião que "(...) coincide com a dissolução dos grandes sistemas, que acompanharam o desenvolvimento da ciência, da técnica e da organização social modernas; e, portanto, igualmente, com o desaparecimento de todo fundamentalismo - dito de outra maneira, com o desaparecimento daquilo mesmo que a consciência comum parece procurar em seu retorno ao religioso" ${ }^{\prime 20}$.

Haveria assim uma aparente contradição entre a necessidade de fundamentos no nível da consciência comum e a redescoberta plausível da religião após a dissolução das "meta-narrações metafísicas", na "sociedade moderna tardia" ${ }^{21}$. A raiz comum da necessidade religiosa da nossa sociedade e de seu retorno na filosofia não poderia, assim, ser compreendida sem uma referência à "modernidade", como época da ciência e da tecnologia. Não se trata para a filosofia de retornar à religiosidade metafísica, fugindo da confusão da modernização e da Babel da sociedade secularizada através de um fundamentalismo renovado, ou seja, "(...) reagir à Babel da pós-modernidade por um retorno a Deus enquanto fundamento"22, opondo uma condição de autenticidade ideal à degenerescência da ciência e da técnica modernas.

Segundo Vattimo, a ultrapassagem da metafísica e de sua fase de extrema dissolução ("a Babel da modernidade tardia e seus medos apocalípticos" ${ }^{\prime 23}$ ) só pode ocorrer, ao contrário, respondendo ao apelo do ser, que só ocorre no acontecimento, isto é, no mundo da ciência, da técnica e da organização total ${ }^{24}$. Foi a dissolução das meta-narrações metafísicas, que permitiu à filosofia redescobrir o caráter plausível da religião, fazendo com que ela pudesse, portanto, "olhar a necessidade religiosa da consciência comum de fora dos esquemas da crí-

\footnotetext{
${ }^{20}$ Ibidem, p. 89.

${ }^{21}$ Ibidem, p. 90.

22 Ibidem, p. 91.

${ }^{23}$ Ibidem, p. 92.

${ }^{24}$ Ibidem, p. 92.
} 
tica do Iluminismo"25. Em outros termos: "A filosofia que coloca o problema do ultrapassamento da metafísica, é a mesma que descobre a positividade na experiência religiosa, mas essa descoberta significa justamente a consciência de sua proveniência"26. Na "pós-modernidade", não seria mais possível falar do ser com a linguagem da estabilidade das essências, em função mesmo do fim dos "meta-relatos".

Portanto, "a religião à qual nós queremos voltar deve se representar como definida por sua pertença à época do fim da metafísica" ${ }^{\prime 27}$. A possibilidade de repensar a religião dependeria, portanto, da compreensão de que o retorno da experiência religiosa ocorre em condições históricas precisas da "modernidade tardia", e que não pode ser definido por um salto fora dela. Não se trata, contudo, de reduzir o divino à imanência da historicidade. Para escapar desse risco, seria importante retomar a perspectiva sobre a relação da experiência religiosa com o mito (tal como ela foi apresentada pela filosofia de Schelling), assim como assumir a perspectiva da irrupção do Outro, que introduz a descontinuidade no horizonte da história ${ }^{28}$. Essa perspectiva, encontra-se, para ele, na referência ao Evangelho, na qual " Deus chama de preferência a ler os sinais dos tempos ${ }^{\prime 2}$.

Vattimo encerra sua intervenção procurando esclarecer o sentido desse núcleo de leitura dos sinais dos tempos, tomando como referência o Novo Testamento e a "doutrina cristã da Encarnação do filho de Deus" na história humana. Essa referência seria o "núcleo mesmo da experiência da eventualidade", permitindo conceber uma leitura dos sinais dos tempos que não se reduz a um puro registro passivo do curso do tempo ${ }^{30}$. A Encarnação não é por ele vista somente como uma maneira de exprimir de modo mítico, o que a filosofia descobre finalmente como resultado de uma pesquisa racional. Ela não seria tampouco uma verdade última, desmistificada e reduzida ao seu sentido próprio, ou seja um enunciado bíblico, que dá lugar ao pensamento pós- metafísico da eventualidade do ser. A descoberta das raízes bíblicas dessa forma de pensamento sobre o ser e a história liga-se, para ele, ao próprio sentido da história. Com a Encarnação, essa deixa de ser apenas uma acumulação de acontecimentos, e abre-se para um sentido emancipador.

No seu esforço de ultrapassar a metafísica, respondendo ao apelo da época, a filosofia torna-se, então, uma hermenêutica, conclui Vattimo ${ }^{31}$.

${ }^{25}$ Ibidem, p. 93.

${ }^{26}$ Ibidem, p. 100.

${ }^{27}$ Ibidem, p. 93.

${ }^{28}$ Ibidem, p. 95.

${ }^{29}$ Ibidem, p. 100.

${ }^{30}$ Ibidem, p. 102.

${ }^{31}$ Ibidem, p. 103. 
É, portanto, importante compreender o sentido e o papel da hermenêutica, na filosofia "pós-moderna", o que me proponho a fazer, a seguir. A hermenêutica abre justamente um campo de estudo extremamente rico para a abordagem da pluralidade do ser e da cultura na multiplicidade de linguagens da Babel "pós-moderna".

\section{Hermenêutica e pluralidade da linguagem}

A hermenêutica (da palavra grega hermeneuein = interpretar), considerada como arte de interpretar, transformou-se na moderna teoria da interpretação dos sinais e elementos simbólicos, na constituição do ser e da cultura. Ela tomou, ao longo da história da filosofia, diversas formas, dependendo da concepção do ser, da linguagem, da cultura e da interpretação utilizadas, podendo fornecer, portanto, uma base filosófica para a pesquisa psicológica, em seu trabalho de elaboração das múltiplas significações da linguagem. Em seu livro, Le Cogito Herméneutique $^{32}$, Jean Greisch traça um quadro da evolução da hermenêutica, partindo de suas raízes em Aristóteles, que pela primeira vez, na história do pensamento, articulou a reflexão sobre o ser à linguagem, considerando que o ser se diz de diferentes maneiras ${ }^{33}$. Assim sendo, embora postulando o ser divino como o primeiro e supremo ser, essa filosofia já abre a perspectiva de pensar as diferenças do ser. Essa colocação é fundamental para o diálogo inter-religioso, pois mesmo partindo da concepção de um único ser divino supremo, pode-se admitir que esse ser possa ser descrito e interpretado de diferentes maneiras.

Com a publicação de Verdade e Método de Georg Gadamer, em 1960, na Alemanha, a hermenêutica filosófica é fundada a partir de uma perspectiva universal, graças à reflexão sobre a linguagem e a interrogação sobre o estatuto próprio das ciências do espírito. Na mesma época, Paul Ricoeur cria, na França, uma concepção original da hermenêutica, baseada num diálogo fecundo com as ciências da linguagem e do texto (em particular com a psicanálise e a história), desenvolvendo uma hermenêutica enraizada no símbolo. Ele constitui, então, uma fenomenologia hermenêutica, com um enfoque fenomenológico mais indireto, que passa pela mediação da linguagem, do texto e das condições sociais e históricas de sua elaboração.

Em Soi-même comme un autre ${ }^{34}$, Paul Ricoeur parte do reconhecimento do inconsciente, da linguagem e da alteridade da consciência, defendendo a idéia da relação do si mesmo ao Outro da consciência,

\footnotetext{
${ }^{32}$ J. GREISCH, Le cogito herméneutique, Paris: Vrin, 2000.

${ }^{33}$ Ibidem, p. 156.

${ }^{34}$ P. RICOEUR, Soi-même comme un autre, Paris: Seuil, 1990.
} 
numa relação de alteridade que passa pela linguagem e pelo símbolo. Para Ricoeur, a compreensão de si integra o conjunto das obras e dos atos, nos quais a vida se desenvolve. Considera ele, que a opção pela consciência imediata encerra o risco de erguer a base filosófica sobre uma falsa consciência. Torna-se, portanto, necessário fazer uma exegese contínua das significações do mundo da cultura, para a elaboração dos significações múltiplas e para o aprofundamento da reflexão. Ele aplica esse método à fenomenologia da religião, para pesquisar os sinais e símbolos do sagrado.

Para Jean Greisch, a grande contribuição da hermenêutica francesa é justamente a de uma ontologia hermenêutica, na qual a compreensão sobre o ser passa pela relação ao símbolo. A originalidade dessa contribuição seria ainda mais extraordinária para esse autor em face à ausência quase total do conceito de símbolo na obra de Heidegger, cuja ontologia da compreensão dirige-se diretamente para a "Analítica do Dasein", sem passar pela análise da linguagem. Ricoeur, ao contrário, partindo da teoria das significações de Husserl, constrói uma ontologia intimamente ligada à linguagem e à possibilidade de transcendência do ser humano, constituindo assim uma fenomenologia hermenêutica.

Uma característica fundamental da filosofia ocidental contemporânea é ter admitido o fim da metafísica e um outro começo filosófico, o do pensamento pós-metafísico. Nele a hermenêutica adquire um lugar central, em função mesmo da multiplicidade das linguagens e interpretações. Na etapa atual, da pós-metafísica ocidental, Jean Greisch considera, contudo, importante para a hermenêutica repensar a questão da transformação e da transcendência do ser humano, levando em consideração as reflexões atuais da filosofia e das ciências humanas a esse respeito. Filósofos franceses, contemporâneos, como Lévinas e Ricoeur, apresentam o si mesmo como não fechado em si, mas aberto para fora e para a interioridade psíquica, formulando a concepção de uma abertura interior para a transcendência.

A hermenêutica da religião, em Ricoeur, parte justamente da experiência religiosa que produz símbolos, narrações e interpretações, dentro de uma comunidade de fé, voltada para a possibilidade de transcendência do ser humano. Sua fenomenologia hermenêutica renuncia a abordar o fenômeno religioso em sua universalidade e transcendência metafísica, buscando a compreensão do discurso religioso dentro de seu contexto sócio-cultural. Isso não exclui, contudo, a possibilidade de se refletir sobre as implicações dos aspectos transcendentais da experiência religiosa de uma comunidade unida pela fé, mas situa a pesquisa de interpretação dos significados em um determinado contexto, exigindo do intérprete o mesmo rigor de escuta em relação aos relatos das diferentes religiões. 
Ricoeur não encara o simbolismo como um sistema fechado de signos. Ele é um sistema aberto, não podendo ser restrito ao sentido linear de uma interpretação lógica. Seu sentido é pluridimensional, ligado às modalidades mais originárias da linguagem e às expressões de fé através das quais os membros de uma comunidade fazem a sua experiência. É, portanto, a experiência viva e histórica de uma comunidade que dá sentido e dinamismo ao texto sagrado ou ao discurso religioso. Essa experiência religiosa e o testemunho sobre ela abrem-se, entretanto, para uma dimensão transcendente. O símbolo ou discurso religioso exprimem, ao mesmo tempo, a relação humana à história e à cultura, na qual a linguagem religiosa é elaborada; e uma relação à dimensão espiritual, da qual o símbolo ou o sinal lingüístico são uma referência, mas cujo sentido os ultrapassa.

A própria relação com a alteridade não é situada por Ricoeur apenas externamente, mas no mais íntimo do ser, onde se estabelece a relação pessoal com Deus. A hermenêutica do si mesmo, delineada mais claramente em Soi-même comme un autre, mostra o ser aberto interiormente para um Outro, que é em última instância o totalmente Outro, ou seja Deus. Nessa perspectiva, a alteridade da consciência é constitutiva e revela a relação ou até mesmo o diálogo interior com o Outro. A pluralidade é, portanto, parte integrante da unidade da experiência vivida. Para Ricoeur, o homem é um ser de transcendência, que ultrapassa constantemente seus limites, mas que carrega em si mesmo o limite da morte e da fraqueza humana. Ele se situa, assim, entre os limites e a estreiteza de sua vida humana e um sentimento de imensidão e de sublime, em relação com essa abertura interior para o mistério do totalmente Outro, que é fundamental para a compreensão da alteridade e da relação do si mesmo e do outro, seja externa ou internamente. Essa visão da pluralidade do eu e da linguagem com seus diferentes significados e interpretações permite, portanto, uma compreensão da Torre de Babel da "pós-modernidade" e de seu pluralismo, inclusive as transformações e reformulações no campo intelectual e religioso, que mostrarei a seguir.

\section{Revisão da modernidade e do enfoque da religião}

Danièle Hervieu-Léger, diretora do Centro de estudos interdisciplinares dos fatos religiosos, descreve a perplexidade atual da sociologia da religião em face ao fato de que a religião, longe de desaparecer, parece ressurgir sob formas diversas, do seio mesmo de uma modernidade a-religiosa. Assim sendo, espanta-se "(...) ao descobrir, na virada dos anos 70, que essa modernidade secular, governada 
pela razão científica e técnica, é uma nebulosa de crenças" ${ }^{\prime \prime 35}$. Considera a autora que faltam "(...) instrumentos para avaliar as transformações, que afetaram a paisagem religiosa contemporânea"36. As discussões sobre a religião se revestiriam, então, sublinha ela, de um tom ideológico e passional, e a mídia não focalizaria senão os aspectos espetaculares e mais superficiais dos fatos religiosos. Mostra ela que a sociologia da religião desenvolve-se, na França, "reduzindo" o religioso ao conjunto de suas determinações sociais.

A atividade sociológica teria contribuído para a racionalização crescente do sistema social e para a eliminação de todo "irracionalismo". "Para muitos pesquisadores, a análise da racionalização do social passava, portanto, primeiro pela elucidação das modalidades da expulsão da religião fora das sociedades modernas. Assim fazendo, eles inscreviam seu próprio trabalho na coerência de um movimento de secularização, implicado pela história da modernização. A medida da queda das práticas religiosas vinha oportunamente confirmar e confortar a problemática da 'redução' da religião, que se impunha a eles como a única abordagem científica possível (...). Para testemunhar a legitimidade científica de seu interesse pela religião, os pesquisadores deviam, de algum modo, confirmar seu desaparecimento" ${ }^{\prime \prime 37}$.

A autora confirma a hipótese de que foi no final dos anos sessenta e início dos anos setenta, que houve a reviravolta decisiva nessa postura em relação à religião. A partir desse momento, passa a haver uma reavaliação do modelo da incompatibilidade entre a modernização e a religião. Tal revisão não afeta apenas a sociologia das religiões, mas abarca uma "colocação em causa da racionalidade do social implicada pelo modelo funcionalista dominante ${ }^{\prime \prime 38}$. No meu entender, essa revisão é muito mais ampla do que ocorreu na sociologia, em particular das religiões, mas essa ilustra muito bem esse processo de crise e transformação da "modernidade", que alguns autores estão chamando de "pós-modernidade". "O retorno com toda força da religião na cena pública, no coração mesmo das sociedades ocidentais, lá onde se supunha que a privatização do religioso era a mais avançada; a colocação em evidência, através da explosão de novos movimentos sociais, de investimentos crentes ligados à mobilização política e cultural; a dispersão das crenças reveladas pela ascensão das religiosidades paralelas e dos novos movimentos religiosos; todos esses fenômenos

${ }^{35}$ D. HERVIEU-LÉGER, Le Pèlerin et le Converti, Paris: Flamarion, 1999, p. 12. Todos os trechos desta obra citados neste artigo são tradução do francês pela autora.

${ }^{36}$ Ibidem, p. 13.

${ }^{37}$ Ibidem, p. 16.

${ }^{38}$ Ibidem, p. 16. 
abriam uma brecha na idéia de uma modernidade 'racionalmente desencantada', definitivamente estrangeira à religião" ${ }^{\prime 39}$.

Os pesquisadores se voltam, então, para o estudo das crenças e seu sentido na experiência subjetiva dos indivíduos, em relação com as práticas, com as linguagens e com as tradições religiosas históricas. Para essa autora, não é a indiferença em relação às crenças, que caracteriza a sociedade atual, mas o fato que “(...) essa crença escapa muito amplamente ao controle das grandes igrejas e instituições religiosas" Descreve ela a atual "proliferação incontrolada das crenças", a tendência à individualização e a subjetivação das crenças, o enfraquecimento das "instituições guardiãs das regras da fé" e a reivindicação da liberdade de construir o próprio sistema de crenças, fora da referência a um corpo de crenças institucionalmente validadas, que pulverizam as crenças, dissolvem os laços estáveis e controlados, tornando relativas as crenças e misturando as fronteiras entre as religiões.

Através de duas figuras consideradas típicas do cenário religioso contemporâneo, Danièle Hervieu-Léger delineia uma das características, que considero como básicas da globalização, a da mobilidade social, salientando a mobilidade ao nível religioso, em termos de religião em movimento. Pinta ela o quadro do "religioso em movimento" através do estudo detalhado do processo de identificação e construção da identidade dessas duas figuras emblemáticas do mobilidade religiosa. Hipotetizando o "fim das identidades históricas herdadas", ela descreve a formação da religião submetida à escolha pessoal, que corresponde à vivência de construção da individualidade própria do ocidente contemporâneo.

Esse novo modo de elaboração da identidade religiosa colocaria em relevo a conquista pessoal, a experiência e autenticidade de um percurso de pesquisa, e não mais a conformidade à verdades garantidas pelas instituições religiosas. Como as sociedades modernas estariam sendo submetidas ao imperativo do imediato, elas estariam deixando cada vez mais de ser sociedades de memória para se tornarem sociedades de mudança, que elegem a inovação como regra de conduta. Com a ruptura da transmissão da memória, o presente domina o horizonte e as crenças dispersas seriam organizadas em função das experiências individuais, que permitiriam construir concretamente as identidades. Caberia, agora, ao indivíduo e não mais à instituição, elaborar seu próprio universo de normas e de valores a partir de sua experiência singular. Ocorreria assim a subjetivação e a pluralização dos processos de construção das identidades religiosas.

\footnotetext{
${ }^{39}$ Ibidem, p. 17.
}

${ }^{40}$ Ibidem, p. 42. 
Em sua tentativa de compreensão das novas formas de religiosidade, Hervieu-Léger dedicou-se ao estudo mais aprofundado da comunidade de Taizé, cuja observação começou desde o início dos anos setenta, acompanhando a transformação dessa comunidade monástica em centro de acolhimento, atraindo jovens de toda Europa e do mundo inteiro e chegando a reunir até seis mil jovens. Essa observação de campo lhe permitiu desvendar a nova característica da peregrinação e seu papel no atual contexto social. Mostra ela como, desde 1977, através de encontros internacionais de jovens, em diferentes cidades européias, o raio de ação dessa comunidade desenha uma "cartografia peregrina da Europa", cria uma "rede de contatos planetários" e um "fórum de encontros intercontinentais", com secretariados em Bombaim, Varsóvia, Caracas, Nova Iorque e Melbourne, permitindo a confrontação de jovens de diferentes culturas. Esses encontros vêm se ampliando: “Esses encontros reúnem - 'fora dos muros' - de 20.0000 jovens (no começo dos encontros) a 120.000 jovens (para os mais recentes)" ${ }^{\prime \prime 4}$.

\section{O papel dos monges na nova religiosidade}

Taizé transforma-se, desse modo, em um símbolo do papel dos monges na Torre de Babel da "pós-modernidade", como assinala um jovem em seu depoimento: "Taizé é uma verdadeira Torre de Babel, há gente de todo lugar com as quais se discute e aí se aprende sempre um monte de coisas"42. A comunidade permite, ao mesmo tempo, a "personalização", a "planetarização" e a manifestação da diversidade (representada pela pluralidade lingüística) entre pessoas muito diferentes (de crentes a não crentes), como sublinha um outro jovem: "cada um aqui se sente um pouco em casa, ninguém é rejeitado; encontramse às vezes irlandeses de cabeça raspada e óculos escuros, que estão reunidos em torno de uma caneca de cerveja, e que cantam com toda força: Jesus, nós te amamos tanto" ${ }^{\prime 4}$.

Essa religiosidade peregrina atual não se reduz, contudo, apenas a Taizé, como se percebe quando a autora analisa as Jornadas Mundiais da Juventude. A que ocorreu em Paris, em agosto de 1977, chegou a reunir, em seu encerramento, um milhão de jovens, vindos de 140 países diferentes, de diversas nacionalidades, línguas, condições sociais e culturais, "(...) testemunhando igualmente a pluralidade de sensibilidades e de correntes religiosas no interior da esfera católica." ${ }^{\prime 4}$.

${ }^{41}$ Ibidem, p. 280.

${ }^{42}$ Ibidem, p. 102

${ }^{43}$ Ibidem, p. 103.

${ }^{44}$ Ibidem, p. 115. 
Diferentes movimentos católicos participam dessas Jornadas Mundiais da Juventude, manifestando a pluralidade e "diversidade da oferta espiritual no interior mesmo do catolicismo" ${ }^{45}$.

Hervieu-Léger, apesar de não ter qualquer vínculo confessional com o catolicismo, apresenta, então, o papa como um ícone dessa religiosidade peregrina: "O papa realiza tanto mais eficazmente essa função de 'operador utópico' da reunião, na medida em que ele se apresenta ele próprio como um 'papa peregrino', percorrendo o planeta em todos os sentidos para responder à sua missão de evangelização" ${ }^{\prime \prime 6}$. Ele é o "peregrino da utopia", associando simbolicamente a universalidade do catolicismo em escala planetária ao movimento da caminhada em direção ao Reino de Deus, observa ela. É nesse sentido, aliás, que a Igreja católica se denomina Igreja peregrina, pois se considera em movimento e apenas de passagem nesse mundo. Essa é a perspectiva na qual se situam os monges, que assinalam de modo radical a ruptura com esse mundo (com a vida mundana) e a abertura e movimento para "novos céus e nova terra".

É importante, portanto, entender o papel dos monges de Taizé, nessa Babel de jovens. Ao mesmo tempo que eles acolhem os jovens em toda liberdade e sem constrangimentos, eles lhes transmitem a segurança de um meio ao mesmo tempo acolhedor e limitador, como expressam as seguintes frases dos jovens: "os irmãos velam", " os irmãos da comunidade sabem evitar os excessos" ${ }^{\prime \prime 7}$. Eles o fazem levando os jovens a participarem da organização cotidiana das atividades e a escolher seu próprio programa, que vai desde a participação na reflexão bíblica, na distribuição das refeições, na meditação ou no canto. A permanência dos jovens na comunidade é sempre transitória, cada um sendo livre de chegar e partir quando quiser, sem nenhuma adesão formal, além da participação mínima nas atividades. A participação litúrgica permite transcender a diversidade, enraizando-a na tradição comum. A leitura do Evangelho numa dezena de línguas assinala a possibilidade de diversidade e unidade em Cristo e a universalidade da Igreja.

Mas o papel fundamental da comunidade monástica, vivendo segundo a Regra monástica de Taizé, é o de abrir o horizonte de um mundo alternativo possível, permitindo uma experiência concreta do Reino de Deus, nos limites desse mundo: " A comunidade manifesta, na forma da radicalidade monástica extra-mundana, o horizonte escatológico ao

\footnotetext{
${ }^{45}$ Ibidem, p. 115.

${ }^{46}$ Ibidem, pp. 117-118.

${ }^{47}$ Ibidem, p. 103.
} 
qual é suposto pretender toda reunião cristã ("a reconciliação perfeita que é da ordem do Reino"). Mas ela incarna, igualmente, a utopia, partilhada por muitos jovens peregrinos, de um mundo harmonioso, sem conflito, onde cada um poderia ser levado - como no canto a várias vozes, conduzido pelos irmãos - a representar sua própria parte, participando da unidade do todo ${ }^{\prime \prime 4}$. A forma de relacionamento religioso peregrino, caracterizado pela mobilidade, diferencia-se da estabilidade monástica da comunidade, mas a ela não se opõe, mas ao contrário, nela se enraíza. A religiosidade peregrina desses jovens, marcada pela mobilidade e pluralidade sociais dominantes, não pode ser dissociada desse eixo monástico, que lhe dá um sentido próprio. Esse sentido deixa de ser percebido, quando a dimensão peregrina é analisada isoladamente, apenas em termos de modalidades de identificações individuais.

Outra características da religiosidade atual, marcada pela mobilidade das crenças e pertenças "é o extraordinário aumento das conversões". A figura do convertido é considerada por Hervieu-Léger como aquela que melhor permite entender o processo de formação das identidades religiosas, no atual contexto de mobilidade. Essa figura ilustra a mentalidade atual, baseada no direito de escolha religiosa. Pareceme, contudo, que esse aumento das conversões decorre também do aumento do intercâmbio e convivência entre as religiões, que não vivem mais separadas umas das outras, encerradas em mundos culturais fechados e estáveis, mas sim num mundo globalizado e de grande mobilidade. Esse fator é determinante, igualmente, na dinâmica das relações inter-religiosas, considerada pela autora como uma das mais interessantes dinâmicas de mudanças significativas, beneficiando do "apoio de uma pesquisa teológica em pleno impulso" $^{\prime 4}$.

Hervieu-Léger descreve o desenvolvimento dessas relações inter-religiosas, na França, como "...uma espantosa proliferação de iniciativas tendendo, no chão das comunidades, a dar um conteúdo concreto à descoberta e troca da experiência espiritual das diferentes tradições" Assim sendo, apesar do apoio oficial da Igreja Católica, consubstanciado em articulações como a do Encontro de Assis e da "...valorização notável das orientações formuladas na Declaração conciliar Nostra Aetate - que se pode considerar, do lado católico, como a carta do diálogo com as outras religiões..." ${ }^{51}$, analisa a autora o surgimento de reações

\footnotetext{
${ }^{48}$ Ibidem, p. 106.

${ }^{49}$ Ibidem, p. 259.

${ }^{50}$ Ibidem, p. 259.

${ }^{51}$ Ibidem, p. 259.
} 
de defesa da "verdadeira tradição" (tanto entre os católicos como entre os protestantes), erguidas não apenas pelas correntes mais tradicionalistas ("que fizeram do combate contra o espírito de Assis a pedra angular da defesa da ortodoxia católica" ${ }^{\prime 52}$ ), mas igualmente, de forma menos violentamente agressiva, pelos meios religiosos "...que têm o sentimento de perder, em face a esse movimento de reconhecimento dos 'valores salutares' das outras religiões, suas referências identitárias" ${ }^{\prime 53}$.

Considerando que as questões levantadas pela vivência ou em torno do diálogo inter-religioso "apresentam um grande interesse do ponto de vista sociológico" ${ }^{\prime 54}$, Hervieu-Léger mostra que, as práticas interreligiosas "estão longe de induzir e amplificar os fenômenos de fracionamento individualista dos crentes, mas constituem, ao contrário, uma forma emergente e inovadora de regulação das identificações crentes às tradições particulares. Os fiéis parecem estar tanto mais inclinados a reconhecer a especificidade da contribuição de sua própria tradição à experiência religiosa da humanidade, quanto eles atestam e valorizam a pluralidade das revelações trazidas pelas tradições dos outros" ${ }^{\prime \prime 5}$. Essa conclusão confirma, portanto, minha tese sobre a importância da alteridade no aprofundamento da própria identidade, confirmada pelo testemunho de vários monges, que participam do DIM.

Uma contribuição decisiva das iniciativas inter-religiosas, por ela colocada em relevo, é a de colaborar para a convergência ética das grandes linhagens religiosas e laicas. Um exemplo recente, por ela fornecido, é o da "Declaração inter-religiosa a respeito da vida política francesa atual", assinada conjuntamente pela Conferência dos Bispos da França, pelo reitor da Grande Mesquita de Paris, pelo presidente do Comitê inter-episcopal ortodoxo da França, pelo presidente do Consistório Central Israelita, pelo Presidente da Federação Protestante da França e pelo Grande Rabino da França, imediatamente após as eleições regionais francesas de março de 1998, manifestando o repúdio às teses racistas, xenófobas e anti-semitas, assim como a necessidade de reencontrar os valores fundadores da democracia. Essa Declaração tornaria visível, ao mesmo tempo, a base ético-política sobre a qual se pode estabelecer a relação entre as diferentes correntes religiosas e laicas, permitindo o reconhecimento da presença das diferentes tradições religiosas na vida pública e na cultura.

${ }^{51}$ Ibidem, p. 259.

${ }^{52}$ Ibidem, p. 260.

${ }^{53}$ Ibidem, p. 260.

${ }^{54}$ Ibidem, pp. 260-261. 


\section{Contribuição do diálogo inter-religioso monástico}

Pode-se constatar, pelas análises de Hervieu-Léger, que ocorreram, nas últimas décadas do século $X X$, modificações profundas não apenas na relação das religiões entre si, mas também no desempenho das religiões, em particular da religião católica por ela estudada, no cenário social. Começa a mudar, ao mesmo tempo, a maneira como as religiões são percebidas e abordadas pelos estudiosos do assunto. É preciso agora relacionar essas mudanças e suas transformações da subjetividade, características do período histórico atual da "pósmodernidade", com a experiência do DIM

Orientei, nesse sentido, minha pesquisa sobre o DIM para o estudo da dimensão da pluralidade, ou da relação ao outro enquanto alteridade. Essa pesquisa se baseia no testemunho de 40 monges católicos, que participam do Diálogo Inter-religioso Monástico, órgão ligado ao Conselho Pontifício para o Diálogo Inter-religioso do Vaticano, que reúne monges de mosteiros católicos do mundo inteiro, participando de comissões de diálogo com monges de outras tradições religiosas. Essa forma de diálogo se distingue do diálogo entre as religiões cristãs ou mesmo monoteístas, por não ter uma referência doutrinária comum, embora os monges católicos, budistas e hindus, que integram as diferentes comissões de diálogo, tenham práticas monásticas semelhantes, relacionadas ao caminho interior para Deus através da contemplação e da ascese. O diálogo inter-religioso está ainda começando, encontra dificuldades na falta de uma linguagem teológica comum, implica um diálogo cultural entre o Oriente e o Ocidente, e se desenvolveu apenas a partir do final do século XX; enquanto que o diálogo ecumênico (entre as religiões cristãs e monoteístas) tem uma base doutrinária e cultural comum, já estando bem mais amadurecido e tendo se desenvolvido há mais de um século.

O estudo do DIM mostrou-me que a concepção cristã da alteridade estimulou o movimento em direção ao outro, ao mesmo tempo que a caminhada do diálogo permitiu o aprofundamento espiritual da experiência positiva da alteridade. A prática do diálogo inter-religioso produziu novas representações sobre o outro e uma nova perspectiva a respeito da relação com as outras religiões. As mudanças a esse respeito encontram sua raiz no caminho interior e na experiência da alteridade radical de Deus, enquanto o totalmente Outro. Contudo, é inegável que os testemunhos sobre a questão exprimem representações elaboradas na experiência da relação social tanto no interior de cada comunidade religiosa como na relação entre os diferentes grupos religiosos e nas diferentes comissões de diálogo. Assim sendo, podese falar de experiência da alteridade e de representação social da 
alteridade, constituídas e transformadas socialmente nas relações comunitárias de monges e monjas, assim como através das relações entre os diferentes grupos religiosos. A prática do DIM mudou a representação social dos monges e monjas católicos, permitindo-lhes uma nova reflexão sobre a alteridade e uma mudança de atitude a respeito do outro enquanto membro de uma religião diferente da católica.

Parece-me, portanto, que esses testemunhos, organizados pelo Secretário Geral do Diálogo Inter-religioso Monástico, Pierre-François de Béthune $^{56}$ demonstram uma rica perspectiva da alteridade. Há um reconhecimento que é preciso aprender a viver, a caminhar e a pensar juntos, fazendo surgir uma gratidão em relação às diferenças, assim como uma compreensão de que essas diferenças existem para o desenvolvimento recíproco. A perspectiva da alteridade é ancorada não apenas na relação ao outro humano, mas também na aceitação da alteridade radical do mistério divino, que determina, em última instância, como as diferentes tradições chegam a Deus. A perspectiva da alteridade muda, desse modo, o próprio sentido da relação entre o eu e o outro, que passa a ser colocada em função dessa relação ao Outro divino. Uma outra mudança fundamental está no fato de se passar a considerar o diálogo não como um meio de converter o outro ao cristianismo, tentando mudar suas idéias, mas como uma ocasião de poder partilhar com os outros, de diferentes religiões, a experiência de amor enraizada na própria descoberta espiritual do Cristo.

Além disso, passa a existir uma nova consciência do momento histórico e do papel dos monges no contexto social. Os monges ligados ao diálogo inter-religioso têm consciência da necessidade do diálogo, no presente momento da história humana, no qual o potencial ideológico e religioso para os conflitos nos coloca diante da possibilidade da destruição total do planeta. A perspectiva de aceitação da alteridade é colocada como a base mesma da possibilidade do diálogo, permitindo ultrapassar o conflito e chegar a uma atitude de escuta e de troca com o outro, sobretudo em face aos horrores das devastações entre os povos e as nações em função das guerras. Recusa-se o seu cortejo de morte e de destruição desenfreada em nome de Deus ou de qualquer outro princípio espiritual que justifique a guerra em nome da religião. Em contraposição a essa perspectiva de morte e destruição, é colocada uma outra perspectiva religiosa com base numa relação amorosa ao outro, tendo como pano de fundo o Outro divino, que é o próprio Amor.

\footnotetext{
${ }^{56}$ P.-F. de BÉTHUNE, «Une expérience d'appauvrissement», in P.-F. de BÉTHUNE (org.), Expériences Monastiques et Dialogue Interreligieux $=$ Bulletin International du DIM n ${ }^{\circ}$ 14, Clerlande: Monastère Saint-André de Clerlande, 2003, pp. 14-16. Todos os trechos desta obra citados neste artigo são tradução do francês pela autora.
} 
Considera Pierre-François de Béthune, então, ser importante diferenciar o diálogo da negociação, da discussão ou da troca de valores respectivos ou a respeito das verdades de cada espiritualidade, evitando mesmo falar de complementaridade entre as religiões, cada qual contribuindo com um ou outro elemento útil, pois isso seria ainda uma maneira muito quantitativa de abordar as religiões, pois o "(...) diálogo concerne nossa vida no que ela tem de mais essencial. Não deve ela ser confundida com uma negociação, uma outra forma de troca, que trata de coisas (territórios, poderes, direitos, heranças, etc.). Com certeza, as negociações são necessárias e, em certas situações, elas são indispensáveis. Conduzidas por 'artesãos da paz' elas são mesmo, às vezes, maravilhosos encaminhamentos evangélicos. Mas elas concernem realidades quantificáveis e procedem, portanto, de um modo que difere nitidamente do diálogo. Ora, como dizia o Patriarca Atenágoras: 'Não se negocia o Inestimável' ${ }^{1 / 57}$. O objetivo desse gênero de diálogo seria, ao contrário, unir-se ao outro através de um encontro de pessoas no nível da experiência religiosa, que seja, ao mesmo tempo, uma descoberta da Presença do Outro divino.

As questões da alteridade e da pluralidade do ser e da cultura são, portanto, centrais no diálogo inter-religioso, que as aprofunda de modo original e extremamente interessante tanto para a religião como para a psicologia. Pierre-François de Béthune, ao escrever sobre as atitudes cristãs nesse tempo de pluralismo religioso, sublinha a importância de um sincero reconhecimento da alteridade religiosa e de sua contribuição para o cristianismo, mostrando, em sua conclusão, como a tradição cristã está sendo revigorada ao levar em conta a esperança e a pesquisa de outras tradições religiosas, ao contrário do que pensam aqueles que temem que ela seja alterada. Não é, contudo, a absorção desses elementos, que justifica para ele a esperança do diálogo, mas o próprio procedimento "(...) de acolhimento do outro, que pode verdadeiramente reavivar nossa própria tradição, pois é um passo essencial no Evangelho, um pouco atrofiado, ao longo de anos de triunfalismo cristão" 58 .

Esse tipo de diálogo ganha cada vez maior atualidade, como mostra uma matéria, publicada no jornal francês Le Monde, em 14 de maio de 2003, a respeito do próximo lançamento de sua revista bimestral, Le Monde des Religions, que tratará exclusivamente dos fatos religiosos, na França e no estrangeiro. Essa revista tem como objetivo respon-

\footnotetext{
${ }^{58}$ Ibidem, p. 15.

${ }^{58}$ Idem, Attitudes chrétiennes en ces temps de pluralisme religieux $=$ Paroles au fil du temps, $\mathrm{n}^{\circ}$ 4, Clerlande: Monastère Saint-André de Clerlande, 2002, p. 17. Tradução da citação do francês pela autora.
} 
der à necessidade de informações, conhecimentos e debates sobre o papel das religiões, criando uma plataforma de encontro para os participantes e especialistas das diferentes religiões a respeito das questões espirituais e políticas mundiais. É particularmente ilustrativo da atual abertura intelectual para o diálogo religioso, o fato da nova revista ter surgido de um acordo entre Les Publications de la Vie Catholique, que editava há cinqüenta anos o periódico Actualités des Religions, e o grupo editorial Le Monde, um dos bastiões da vida intelectual francesa. A matéria sublinha que, na época do predomínio do existencialismo e do marxismo, pensava-se que Deus estava morto, mas que ocorre uma reviravolta a esse respeito no início do século XXI, na medida em que o fato religioso torna-se uma das principais chaves da compreensão do mundo e das tensões internacionais. $\mathrm{O}$ diálogo inter-religioso amplia-se assim para o mundo intelectual e até mesmo para aqueles afastados da religião, permitindo, desse modo, uma abertura para a escuta, interpretação e acolhimento da alteridade de outros seres humanos, culturas e religiões.

Olga Sodré, psicóloga, atualmente faz um doutorado em psicologia sobre o diálogo inter-religioso monástico na PUC-Rio. É Mestra em Psicologia Clínica pela PUCRJ, 1989 ("CIDVILASA, o Jogo da Energia Divina - Teoria e Experiência do Eu: O Ator a Fantasia e seus Personagens, segundo a psicologia da ioga"), Doutora em Filosofia pela Sorbonne / Paris IV, França, 1985 ("La Nature humaine et L’Énergie Consciente" [tese sobre a filosofia indiana do Shivaísmo da Caxemira]), e Pósdoutorada em Filosofia, no Laboratório de Pesquisa em Teologia Filosófica e Filosofia da Religião do Institut Catholique de Paris, 2000/2001, com relatório de síntese voltado para a psicologia da religião. Lecionou em diferentes universidades no nível da licenciatura e mestrado, em particular na Université de Sciences Humaines Cliniques (Paris VII), no Institut de l'Environnement de Paris, na UERJ, e na PUC-Rio. Trabalha atualmente como psicóloga clínica autônoma.

Endereço: Rua Barão de Ipanema, 139/202

22050-030 Rio de Janeiro - RJ

e-mail: olgasodre@openlink.com.br 


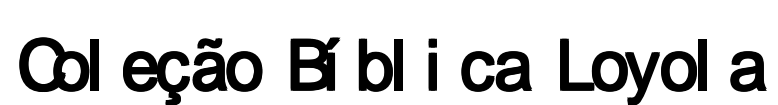

Publicada sob a responsabilidade da Faculdade de Teologia do Centro de Estudos Superiores da Companhia de Jesus.

A Coleção Bíblica Loyola publica estudos, comentários e subsídios bíblicos de nível científico internacional, seja traduzidos do exterior, seja produzidos por biblistas nacionais.

\section{Títulos Publicados}

1. Os Evangelhos I - Mateus e Marcos (G. Barbaglio e R. Fabris)

2. Os Evangelhos II - Lucas e João (R. Fabris e B. Maggioni)

3. Os Atos dos Apóstolos (R. Fabris)

4. As Cartas de Paulo I - Tessalonicenses e Coríntios (G. Barbaglio)

5. As Cartas de Paulo II - Gálatas, Romanos, Filipenses e Filêmon (G. Barbaglio)

6. As Cartas de Paulo III - Colossenses, Efésios, Pastorais e Hebreus (R. Fabris)

7a. A Carta de Tiago (F. Vouga)

7b. As Cartas de Pedro, João e Judas (G. Thevissen et alii)

8. O Apocalipse (P. Prigent)

9. A palavra inspirada (L. Alonso Schökel)

10. A Bíblia como literatura (J. B. Gabel e Ch. B. Wheeler)

11. Cântico dos Cânticos (L. I. Stadelmann)

12. Metodologia do Novo Testamento (W. Egger)

13. Leitura do Evangelho Segundo João I (X. Léon-Dufour)

14. Leitura do Evangelho Segundo João II (X. Léon-Dufour)

15. Leitura do Evangelho Segundo João III (X. Léon-Dufour)

16. Leitura do Evangelho Segundo João IV (X. Léon-Dufour)

17. Jesus e o mundo do judaísmo (G. Vermes)

18. A Galiléia, Jesus e os Evangelhos (S. Freyne)

19. As duas fases da pregação de Paulo (M. Pesce)

20. O Evangelho de Mateus e o judaísmo formativo (J.A. Overman)

21. A Bíblia na Igreja (J.A. Fitzmyer)

22. O pensamento do templo. De Jerusalém a Qumran ( $F$. Schmidt)

23. As formas literárias do Novo Testamento (K. Berger)

24. Procurais o Jesus histórico? (R. Zuurmond)

25. Sabedoria e sábios em Israel (J. Vílchez Líndez)

26. Mulher e homem em Paulo (N. Baumert)

27. A evolução do pensamento paulino (U. Schnelle)

28. Metodologia do Antigo Testamento (H. Simian-Yofre [org.])

29. A mensagem do Reino (R. A. Horsley e N. A. Silberman)

30. Abraão e sua lenda: Gênesis 12,1-25,11 (W. Vogels)

31. Israel e seu Deus: (F. Gradl e F. J. Stendebach)

32. Sacrifício e culto no Israel do Antigo Testamento: (Ina Willi-Plein)

33. O Jesus Histórico: (Gerd Theissen / Annete Merz)

Edições Loyola - Cx. P. 42.355 - CEP 04299-970 São Paulo e-mail: vendas@loyola.com.br 